\title{
SNOW COVER AND GLACIER DYNAMICS STUDY USING C-AND L-BAND SAR DATASETS IN PARTS OF NORTH WEST HIMALAYA
}

\author{
Praveen K. Thakur ${ }^{1 *}$, Vaibhav Garg ${ }^{1}$, Bhaskar R. Nikam ${ }^{1}$, Sachchidanand Singh $^{3}$, Jasmine ${ }^{4}$, Arpit Chouksey ${ }^{1}$, Pankaj R. Dhote ${ }^{1}$, S.P. \\ Aggarwal $^{1}$, Prakash Chauhan ${ }^{1}$, A Senthil Kumar ${ }^{1,2}$ \\ ${ }^{1}$ Indian Institute of Remote Sensing, Dehradun, (praveen, vaibhav, bhaskarnikam, arpit, pdh, spa, prakash)@iirs.gov.in \\ ${ }^{2}$ Centre for Space Science and Technology Education in Asia Pacific (CSSTEAP), IIRS campus Dehradun (senthil@iirs.gov.in) \\ ${ }^{3}$ M.Tech Student, Indian Institute of Remote Sensing, Dehradun (sachinlnt1811@gmail.com) \\ ${ }^{4}$ Amity Institute of Geo-informatics and Remote Sensing, Amity University, Noida, India (jasminechawla73@gmail.com)
}

\section{Commission V, SS: Natural Resources Management}

KEY WORDS: Snow cover, glacier dynamics, SAR data, Glacier velocity, InSAR, North West Himalaya

\begin{abstract}
:
The seasonal snow cover and permanent ice in form of Himalayan glaciers provide fresh water to many perineal rivers of Himalayas. The melt water from seasonal snow and glaciers, especially during of 15 March to 15 June acts as important source of water for drinking, hydropower and irrigation requirements of many areas in North India. This work has highlights the use of C-band Synthetic Aperture Radar (SAR) data from RISAT-1, Sentinel-1A and 1B satellites and ALOS-PALSAR-2 PolInSAR data for snow cover and glacier dynamics study for parts of North West Himalaya. Glacier velocity was derived using InSAR based method using 6 day temporal interval images from Sentinel-1 satellites and 14 day interval for PALSAR-2 satellite. High coherence was obtained for main glacier in both the data sets, which resulted accurate line of site (LOS) glacier velocity estimates for test glaciers. These InSAR data glacier velocity results are obtained after a gap of 21 years. Glacier facies was estimated using multi-temporal SAR image composition based classification. All these maps were verified by extensive ground surveys done at these sites during 2014-2017. The time series data of C-band SAR in VV/VH polarisation was also used to map snow cover in test basins of Bhagirathi and Beas River. The VV/VH data clearly shows difference between dry and wet snow, thus helping in improved snow cover mapping using SAR data. This study will help in refining algorithms to be used for such studies using upcoming NASA-ISRO SAR (NISAR) mission.
\end{abstract}

\section{INTRODUCTION}

The seasonal snow cover and glacier are the globally recognised essential climate variables (WMO-2017), which controls the water availability in head water Himalayan watershed and rivers basins (Singh and Kumar 1997, 2007). The brief about snow cover and glacier mapping and monitoring using remote sensing, the gap areas and objectives are given in this section.

\subsection{Snow Cover}

The Seasonal Snow Cover (SSC) in Indian Himalayan Region (IHR) is fed mainly by North West winter monsoon or Western Disturbances, WDs (Dimri et al., 2015) in mid and high elevation areas $(>1800 \mathrm{~m})$ and also in parts by South West Indian Summer Monsoon (ISM) mainly in higher elevation zones $(>5000 \mathrm{~m})$, mainly due to elevation induced lapse rate and low temperature in high elevation areas (Pepin and Lundquist, 2008; Thayyen and Dimri, 2018). The snow accumulates during the winter till March April and melts during spring and summer months, with minimum snow cover at the end of ablation season, i.e. last week of August (Thakur et al., 2017a,b). This snow melt is also augmented by glacier melt, which contributes significantly during ablation season (June-August) and minimum glacier melt in winters (Dobhal et al ; Agrawal et al., 2017). The vast and high relief areas of IHR including North West Himalaya (NWH) region cannot be accessed using traditional ground based field surveys. Therefore, Remote Sensing (RS) remain one of most important and feasible technology to map and monitor the SSC and its physical properties at various spatio-temporal scales, as proven by many operational and research studies (Kulkarni et al ; Thakur et al., 2012, 2017a,b; Jain et al., Negi et al., Sharma et al., Nikam et al., 2017). The RS based snow cover and its properties have direct use as input to snowmelt runoff models (Jain et al., 2009; 2010; Prasad and Roy, 2005; Thakur et al., 2009; Aggarwal et al., 2013; Thakur, 2014; Wulf et al., 2016), and as validation and data assimilation in process based hydrological models (Naha et al., 2016; Agarwal et al., 2016). The optical data is capable of giving good quality snow cover maps, but synthetic aperture radar (SAR) data is able to provide, dry/wet snow and snow physical properties as well, due to penetration capability and sensitivity to snow wetness (Singh and Venkataraman 2007, 2009; Thakur et al., 2012; Snapir et al., 2019). The only major limitation of SAR sensors is no penetration when snow is wet, less temporal resolution and operations in single wavelength (Hallikainen et al., 2001; Thakur et al., 2012).

\subsection{Glacier Dynamics}

The glacier are defined as moving rivers of ice (Paterson, 1994; Pellika and Rees, 2009). The Himalayan glacier are always located above approximately $4000 \mathrm{~m}$ elevation and are generally difficult in-accessible terrains. The RS remain one of most popular technologies to map and monitor these icy rivers, which provides an important contribution to river flow in head water river basins of NWH such as Indus, Beas, Satluj and Ganga (Singh and Singh, 2001, Singh and Jain, 2002). These glacier are highly sensitive to short and long term variations in temperature and precipitation variations, as well as climate change, and in last 50 years, most of these glaciers have shown negative mass balance and snout retreat (Wagnon et al., 2007; Bhambari and Bolch 2011; Bolch et al., 2012, Dobhal et al., 2008; Azam et al., 2012; Sharma et al., 2013; Pratap et al., 2016) as observed by

\footnotetext{
* Corresponding author
} 
remote sensing and traditional ground based glaciological measurements. The dynamics of these glacier can be effectively observed and mapped by RS based methods (Bhambari et al., 2012), which can quantity its area, length and elevation changes over time, as well as its surface velocity and glacier facies (Joughin, 2010; Berthier et al., 2005; Kumar et al, 2011; Bhardwaj et al., 2015; Thakur et al., 2016, 2017a, b). The vast amount of free and multi-temporal optical and SAR data from various space agencies have opened new applications in the field of glacier dynamics monitoring. Therefore, this work is intended to showcase a few of such glaciology applications using free RS datasets, and their utility in monitoring the overall health of Himalayan glaciers

\subsection{Objectives}

The main objectives of the present work are to map dry and wet snow cover using freely available SAR data, to map the glacier facies using multi-temporal freely available C-band SAR data and to estimate glacier velocity using DInSAR (C and L band) and optical datasets. In addition, the tandem-x data was also used for elevation estimation of few selected glaciers.

\section{STUDY AREA AND DATA USED}

\subsection{Study Area}

The study area for SAR based snow cover analysis is Beas River and Upper Ganga River basins in Himachal Pradesh and Uttarakhand states of India. The Figure 1 shows the location of these basin in India. The study area for Glacier dynamics is few major glaciers of NWH, such as Siachen, Gangotri and Bara Shigari glaciers, as shown in Figure 2. These three glacier are the longest and largest in terms of length and total area, in Indian Himalayas, and they fall in Indus, Ganga and Chenab river basin head watersheds, respectively.

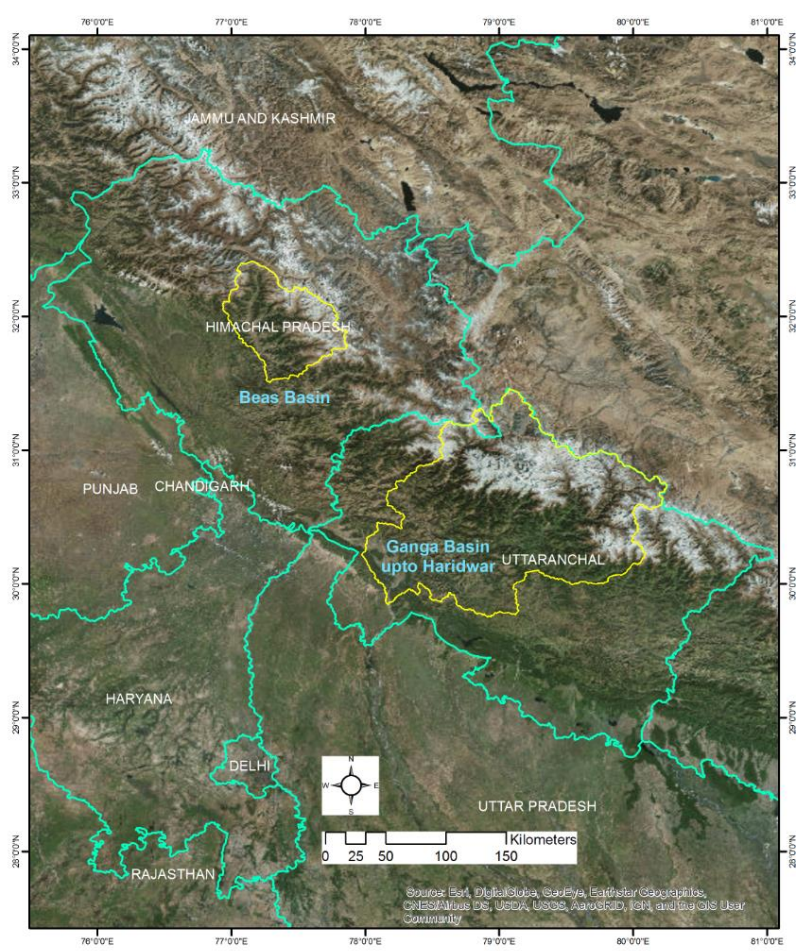

Figure 1: Selected rivers basins (Beas and Upper Ganga) for SAR based snow cover study.

The total area of Beas basin upto Thalot and Ganga basin upto Haridwar is $4975 \mathrm{~km}^{2}$ and $23,177 \mathrm{~km}^{2}$, respectively. The maximum and minimum snow cover area in these basins varies from 20 to $80 \%$ for Beas and 20 to $60 \%$ for Ganga. The relative contribution of snow melt to total river discharge is highest in the headwater catchments and it decreases significantly as we move further downstream.

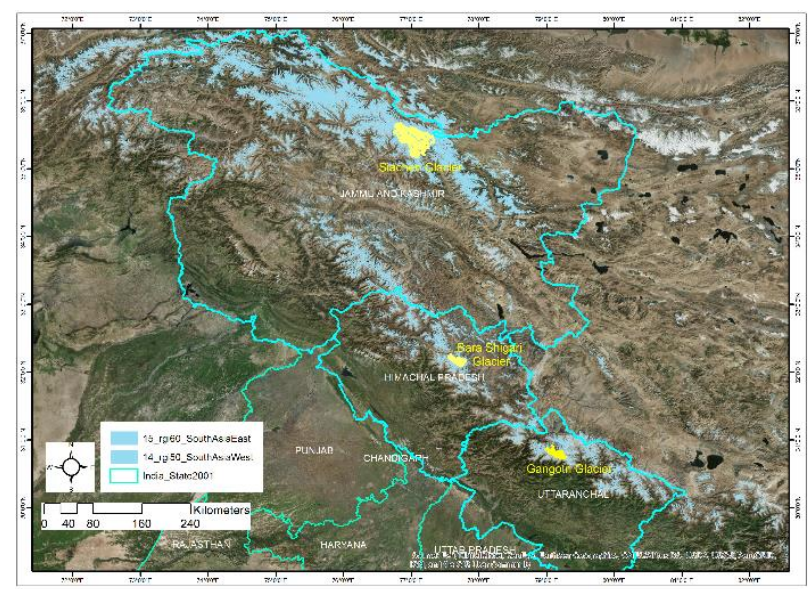

Figure 2: Selected glaciers (Siachen, Gangotri and Bara Shigari) for glacier dynamics study in NWH region (The background RS data is from Digital Globe and USGS).

\subsection{Data Used}

The free ALOS-PALSAR-2 data was provided by JAXA announcement of opportunity science project, RISAT-1 data was procured from National Remote Sensing Centre's (NRSC's), India national data centre (NDC) and Sentinel $1 \mathrm{~A} \& 1 \mathrm{~B}$ data was taken from Alaska SAR facility. Earlier studies using Interferometric SAR (InSAR) data for Himalayan glaciers has suffered from loss of coherence due to low temporal resolution of SAR images and high glacier velocity. In addition, TANDEMx data of year 2012 and 2013 was also used to derive temporal elevation changes due to dynamic snow/ice condition of Gangotri glacier. The time series of SAR data from RISAT-1 and Sentinel1 satellites was used for glacier in Chenab and Gangotri basins, for creating SAR image composites, identify and map radar glacier zones such as debris ice, percolation-refreeze zone, wet snow and dry snow zones. The ascending and descending passes of Sentinel-1 SAR data has given temporal coverage of 4 to 6 days to map and study the snow cover and the glacier dynamics in test basins of NWH. All SAR data was processed using Sentinel-1 toolbox (SNAP) of ESA (ESA, SNAP, 2017).

\section{METHODOLOGY}

\subsection{Snow Cover Dynamics Using C-Band SAR Data}

The main approach of estimating the dry, wet and total snow cover is similar to the earlier studies (Nagler and Rott, 2000, Thakur et al., 2016), however, the input data is C-band SAR from Sentinel-1A/1B satellites and algorithm uses Google earth Engine (GEE) codes to access, and analyses time series data, as recently demonstrated by (Snapir et al., 2019). The VH polarization is used with Sentienl-1 data, as it has shown higher sensitivity to dry and wet snow (Thakur et al., 2016) as compared to the $\mathrm{VV}$ polarization. The brief methodology flow chart is given in figure 3 . 


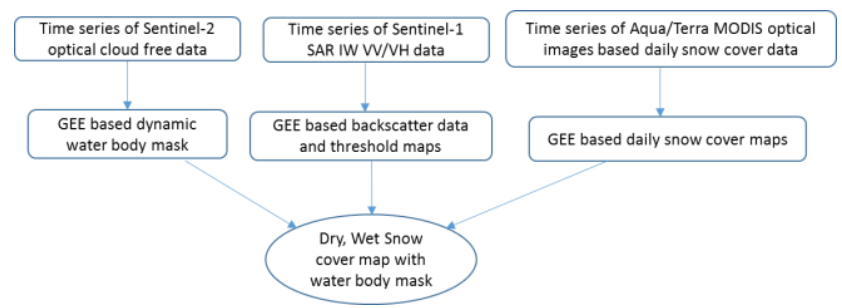

Figure 3: SAR based snow cover mapping methodology

\subsection{Glacier Dynamics Using SAR/Optical Data}

The glacier dynamics is studied by estimating the surface glacier velocity and mapping of glacier radar zones using SAR datasets. The DInSAR based glacier velocity method employed in the present study is given in Figure 4.

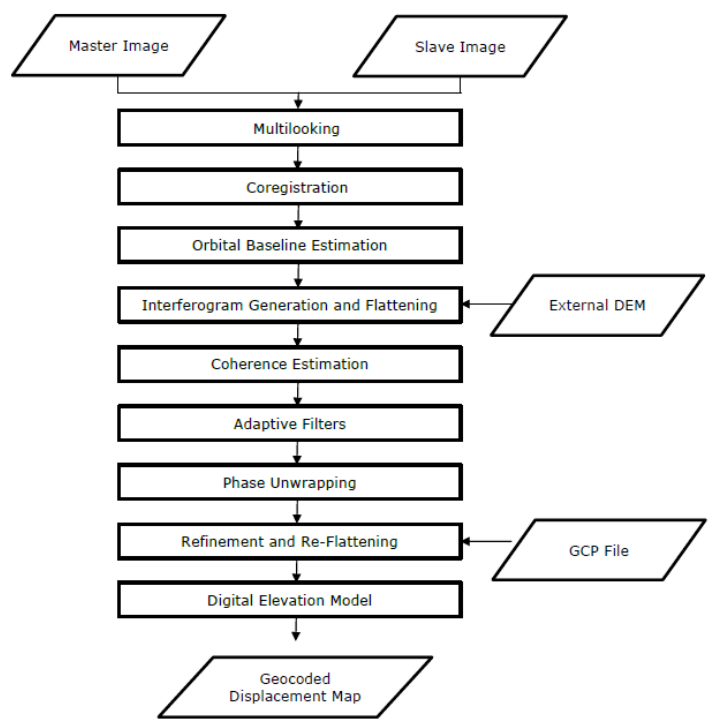

Figure 4: Glacier velocity estimation using DInSAR data (adopted from Thakur et al., 2016).

In both cases of co-registration and re-flattening, SRTM-x band $30 \mathrm{~m}$ DEM (Farr et al., 2007) was used to remove topographic phase due to its better resolution and vertical accuracy.

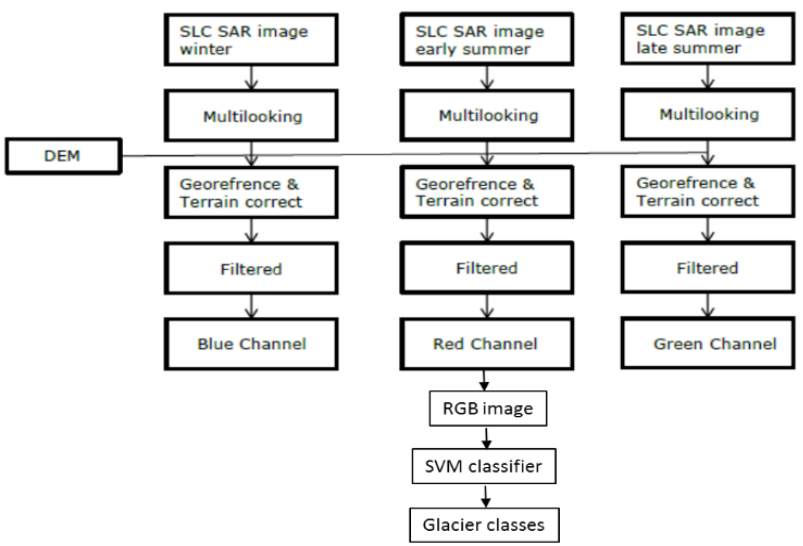

Figure 5 Glacier facies mapping approach (Thakur et al., 2016; Sood, 2015).

The multi-temporal SAR image based composite method is used for identification of the glacier facies (Figure 5), this approach was first used by Patrington (1998) and has proven its utility using RISAT-1 based datasets for Gangotri glacier (Thakur et al., 2017a). The support vector machine (SVM) method of supervised image classification is used with SAR colour composite image for final glacier facies mapping.

\section{RESULTS AND DISCUSSIONS}

The results section is divided into two sub-sections, the first subsection gives SAR based dry, wet snow cover mapping results and next sub-section gives main results of glacier velocity and facies mapping for selected glaciers of NWH.

\subsection{Snow Cover Results}

The C-band SAR based results for study area are shown in Figures 6 and 7. The variable and multiple threshold approach is used to classify the snow as dry and wet snow in both the case. The wet snow is taken below $-20 \mathrm{db}$ and dry snow above $-5 \mathrm{db}$, with 0 and above values taken as layover or double bounce features. The Google Earth Engine (GEE) is used (Gorelick et al., 2017) to select and download the Sentinel-1 SAR data. The Threshold and final mapping is completed in the ArcGIS software. The both Ganga and Beas basin are covered with a single full scene of Sentinel-1 data in descending mode, hence snow maps of this region can be generated for every 6,12 or 24 day time interval.

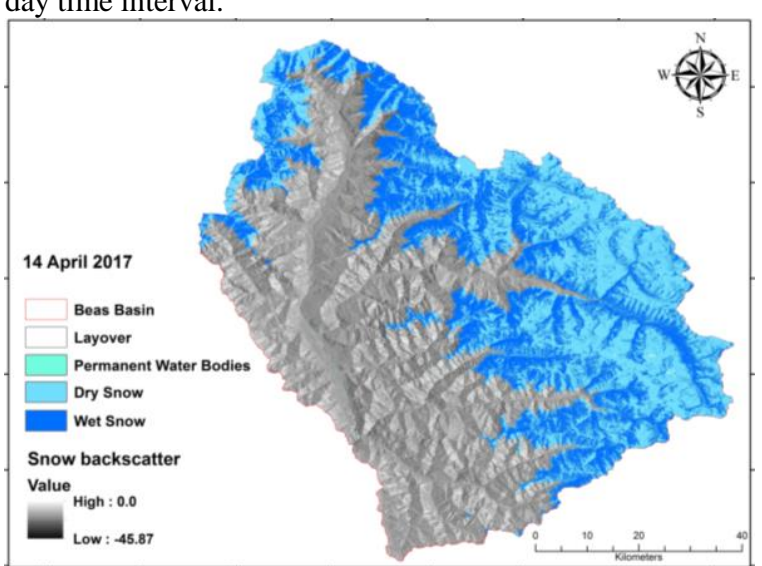

Figure 6: SAR based snow cover of Ganga basin upto Haridwar

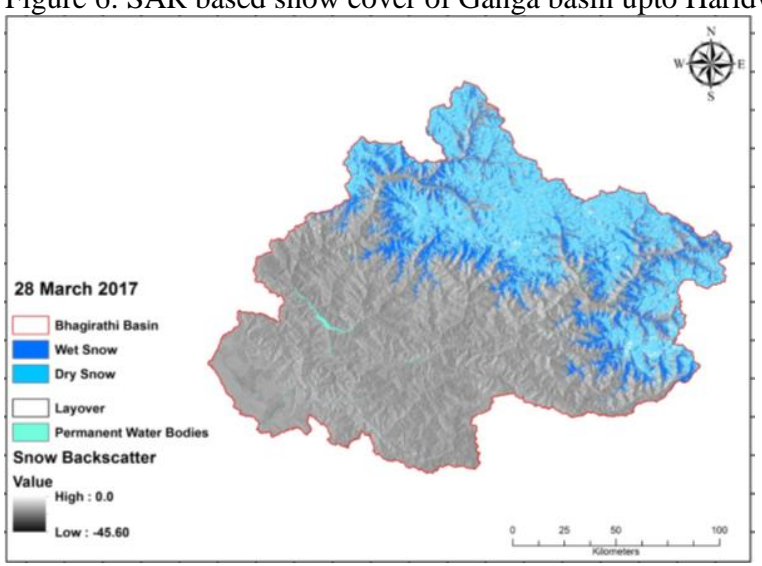

Figure 7: SAR based snow cover of Beas basin upto Thalot

Total $37.06 \%$ of Ganga basin was covered with snow, out of which, $23.61 \%$ are had dry snow and $13.45 \%$ was covered with wet snow for 28 March 2017. The Beas basin has total snow cover of $56.85 \%$, with dry snow of $29.38 \%$ and wet snow of $27.47 \%$ on 14 April 2017. The wet snow in Beas basin was higher as compared to Ganga basin, mainly due the late spring time period. The accuracy of SAR based snow maps is more than $95 \%$, when compared with MODIS based snow maps. The layover mask will also reduce some of the usable area $(>10 \%)$ in 
the case of Sentinel-1 SAR datasets, as they have fixed incidence angle range $\left(32.9^{\circ}\right.$ for IW1, 38.3 for IW2 and 43.1 for IW3)

These are initial results and work is in progress to create long duration weekly or 10 daily time series of dry and wet snow cover maps using Sentinel-1 SAR data and reference image threshold approach (Nagler and Rott, 2000; Thakur et. al., 2013). This can be an improvement over monthly snow maps as derived by Snapir et al., (2019).

\subsection{Glacier Dynamics Results}

The glacier dynamics, the variation in the glacier surface velocity and glacier facies have been estimated using SAR based data and presented in this section.

4.2.1 Glacier velocity estimation: The DInSAR data from Sentinal-1A satellite have been processed for three major glaciers of NWH. The results are shown from Figures 8 to 13. The coherence for main parts and trunk glacier of these test sites was higher than 0.8 , mainly due to the 6 day interval Sentinel-1 InSAR datasets.

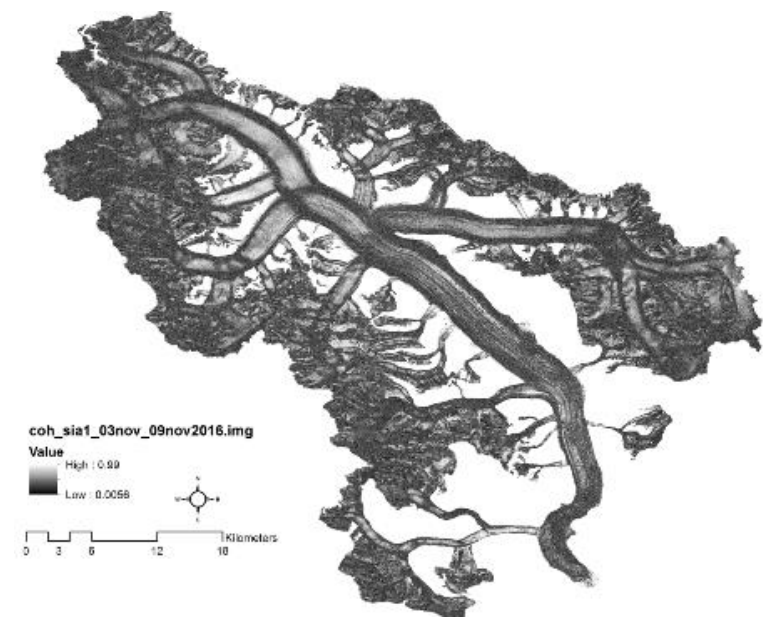

Figure 8: Coherence map of Siachen glacier

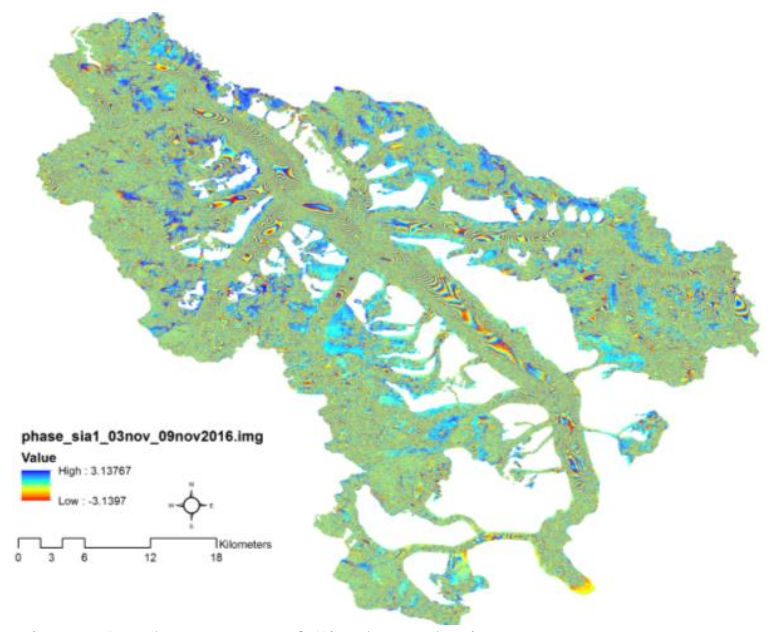

Figure 8: Phase map of Siachen glacier

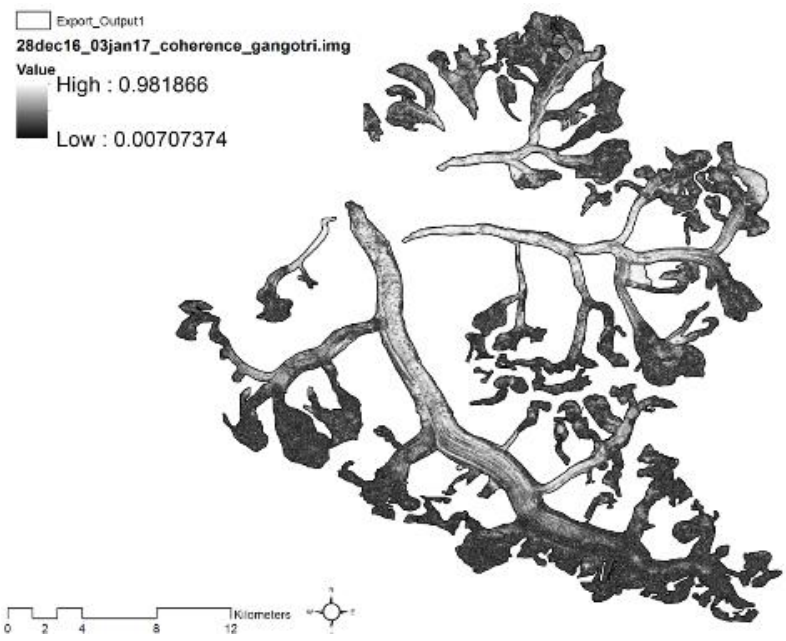

Figure 10: Coherence map of Gangotri glacier

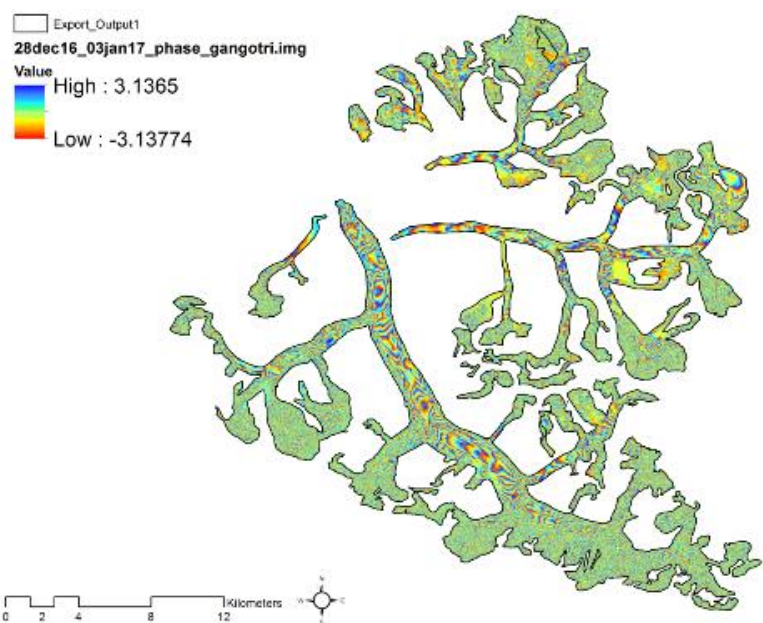

Figure 11: Phase map of Gangotri glacier

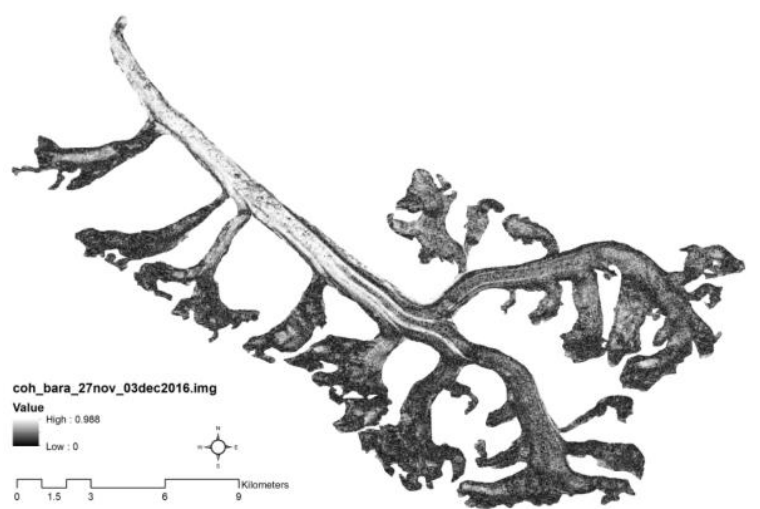

Figure 12: Coherence map of Bara Shigri glacier 


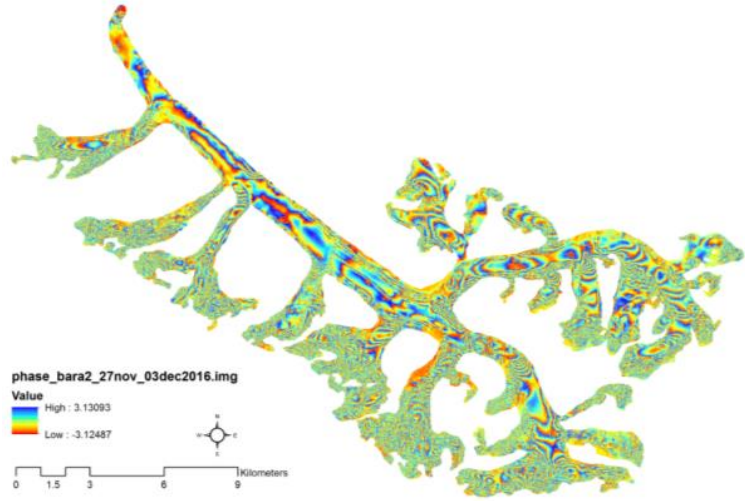

Figure 13: Phase map of Bara Shigri glacier

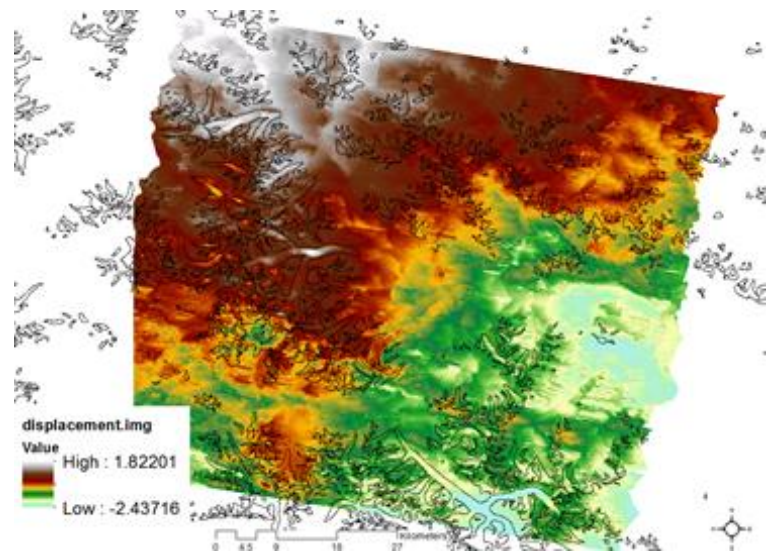

Figure 14: LoS glacier velocity using PALSAR-2 for glaciers of Chandra basin, 10-24 Mar 2015.

The 6 day interval line of Site (LoS) glacier velocity was estimated as $-0.037 \mathrm{~m} /$ day to $+0.139 \mathrm{~m} /$ day, $-0.07 \mathrm{~m} /$ day to $+0.055 \mathrm{~m} /$ day and $-0.041 \mathrm{~m} /$ day to $+0.19 \mathrm{~m} /$ day for Siachen, Gangotri and Bara Shigri glaciers, respectively, with +ve indicating velocity vector towards the satellite and -ve values indicating velocity in away from satellite look direction. Similarly 14 day interval ALOS-APLSAR-2 data was used for glacier LoS velocity estimation in Chandra Basin of Chenab River, covering Smudra Tapu, Batal, Chota and Bara Shigri glaciers. The LoS glacier velocity for Chandra basin glacier is shown in Figure 13, with value ranging from $-0.176 \mathrm{~m}$ to +0.13 $\mathrm{m} /$ day in 14 days. The 6 day interval InSAR data from Sentinel1 is available for more winter dates of 2016-2017 and 2017-2018, and can give seasonal to annual estimation of glacier velocity in Himalaya.

4.2.2 Glacier facies mapping: The results of multi-temporal SAR image colour composite based glacier facies identification and mapping are given in this sub-section. In all the colour composites, the red colour is assigned to early summer (AprilMay) image, Green to late summer (August end) and Blue to winter (January-February) SAR images, as demonstrated in previous studies (Sood, 2015; Thakur et al., 2016, 2017a). This composite image is used for SVM based supervised classification of glacier facies. The sample VV/VH images for three dates/seasons for Siachen glacier of Karakorum Himalaya along with other results are shown in Figures 15 to 19.

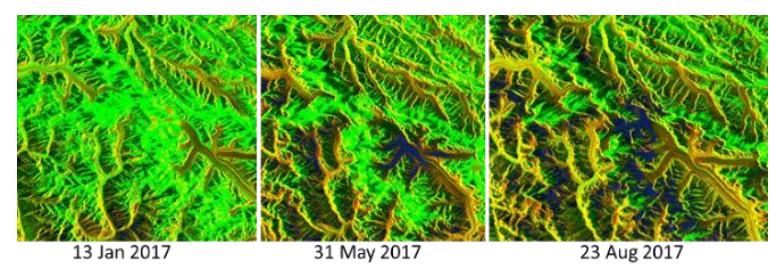

Figure: 15: Seasonal Sentiel-1 SAR data for Siachen glacier

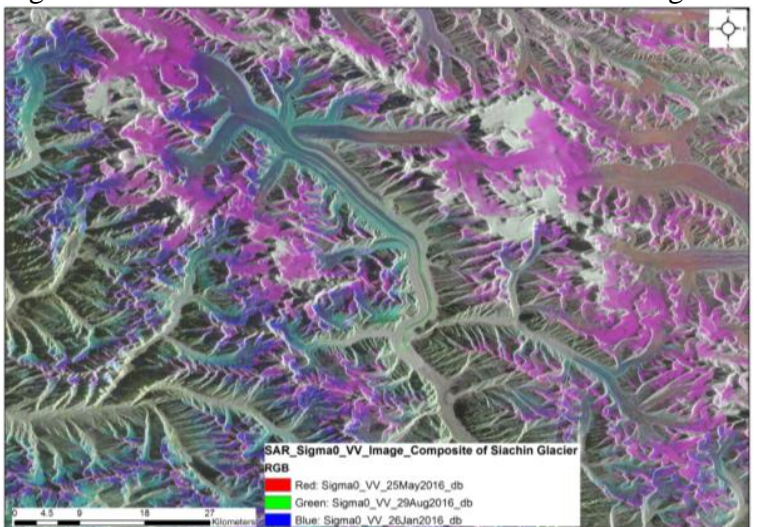

Figure 16: SAR image composite of Siachen glacier (2015).

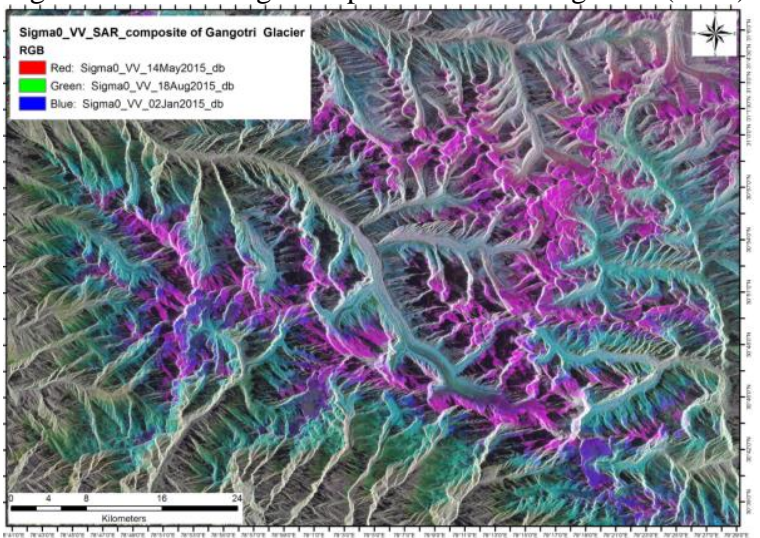

Figure 17: SAR image composite of Gangotri glacier (2015).

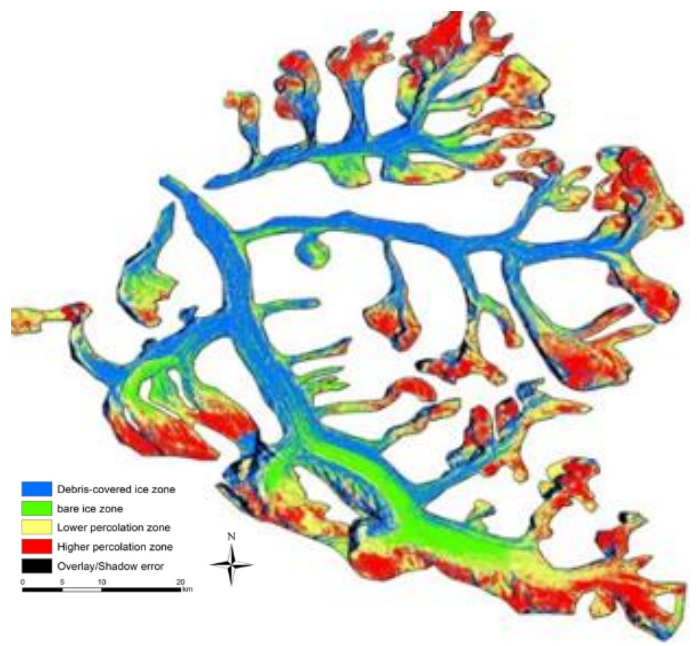

Figure 18: SAR based glacier facies of Gangotri glacier (2015). 


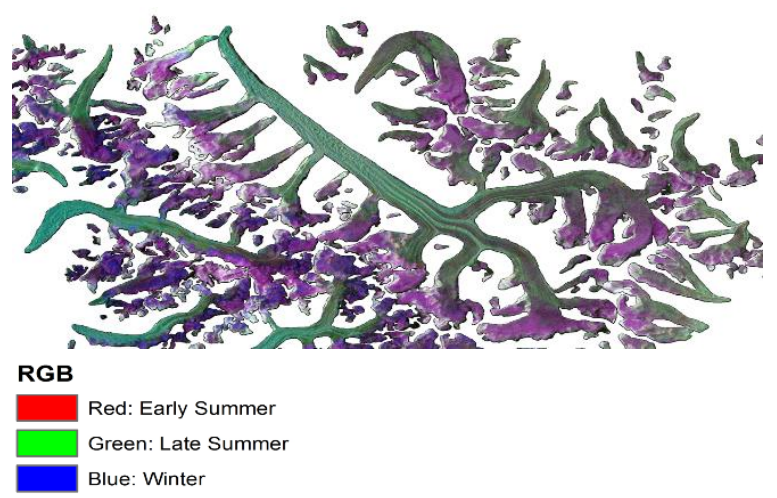

Figure 19: Multi-temporal SAR image composite of Bara Shigri glacier (2015).

Glacier facies can be easily identified in all the SAR based temporal composites (Figure 16 to 18 ), with light grey, purple and blueish showing presence of percolation-freeze zone in higher, middle and lower elevations of a glacier. Green, mixed green blue showing clean or bare ice, and dark grey as dry snow zone (Patrington, 1998; Thakur et al., 2016, 2017a, b). The SVM based supervised classification method was used to map glacier facies classes such as debris cover glacier ice, bare ice, percolation-refreeze radar zone in various elevations, wet snow and supra-glacier lakes with Sentinel-1 datasets for these glacier, with sample map shown for Gangotri glacier (Figure 18). The annual time series maps of glacier facies can be easily used to identify and map accumulation and ablation zones, along with equilibrium line altitude (ELA) of a glacier, thereby giving direct input or indicating about heath of mapped glacier (Thakur et al., $2016,2017 \mathrm{a}, \mathrm{b})$, in a given water year.

\section{CONCLUSIONS}

The study has again proven significant improvement in application of SAR data for snow cover mapping and glacier health monitoring, if systematic and long duration time series data is available (Sentnel-1 in present case), as also proven in the previous study with RISAT-1 data (Thakur et al., 2017a). The snow cover in terms of dry and wet snow was successfully estimated using C-band SAR data with VH backscatter images for Ganga and Beas River basins. The Sentinel 1A/1B data with 6 to 12 day interval can be used for operational wet/dry snow mapping in Himalayas, if we combine both descending and ascending pass data at 8 daily time scale, and this will be complimentary to optical images based operational snow cover maps.

This study is also significant, as it shows for the first time use of freely available InSAR/SAR data of Sentinel-1 for glacier velocity and glacier facies mapping in all major glaciers of $\mathrm{NWH}$. The derived glacier velocity is reported in LoS glacier values only, and further work is required to covert this $\operatorname{LoS}$ data into actual glacier velocity using horizontal glacier flow assumption and use of external Digital Elevation Model (DEM) (Wangensteen et al., 2005). The 3D glacier velocity can also be estimated if both Descending and Ascending pass InSAR data is made available (e.g., Kumar et al., 2011) by European Space Agency (ESA) at 6 day interval, in near future, as at present, only descending mode data is available with 6 day interval for selected time and glacier of Himalaya. The results generated and experience gained from the present study will help in improving algorithms to be used for such studies using upcoming NASAISRO SAR (NISAR) mission.

\section{ACKNOWLEDGEMENTS}

The authors thanks the ISRO, ESA, JAXA, NASA and USGS for providing the satellite data and data products used in this project. The ALOS-PALSAR-2 data was provided by JAXA under RA4 project (PI No: 1408) to first author under topic "Hydrological parameter retrieval and glacier dynamics study with l-band SAR data".

\section{REFERENCES}

Aggarwal, S.P., Thakur, P.K., Nikam, B.R., Garg, V., 2014. Integrated approach for Snowmelt Runoff Estimation using Temperature Index Model, Remote sensing and GIS. Curr Sci., 106(3), pp.397-407.

Agrawal, A., Thayyen, R. J. and Dimri, A. P., 2017. Massbalance modelling of Gangotri glacier. Geological Society, London, Special Publications, 462,

Azam, M.F., Wagnon. P., Ramanathan, A., Vincent, C., Sharma, P., Arnaud, Y., Linda, A., Pottakkal, J.G., Chevallier, P., Singh, V.B., Berthier, E., 2012. From balance to imbalance: a shift in the dynamic behaviour of ChhotaShigri Glacier (Western Himalaya, India). J Glaciol., 58(208), pp.315-324.

Berthiera, E., Vadonb, H.,Baratouxc, D., Arnaudd, Y.Vincente, C., Feiglc, K.L.,Rémya, F. and Legrés, B., 2005. Surface motion of mountain glaciers derived from satellite optical imagery. Remote Sens Environ., 95(1), pp.14-28.

Bhambri, R., Bolch, T., Chaujar, R.K., Kulshreshta, S.C., 2011. Glacier changes in the Garhwal Himalaya, India 1968-2006 based on remote sensing. J Glaciol, 57(203), pp.543-556.

Bhambri, R., Bolch, T. and Chaujar, R.K., 2012. Frontal recession of Gangotri Glacier, Garhwal Himalaya, from 1965 to 2006, measured through high resolution remote sensing data. Curr Sci., 102, pp.489494.

Bhambri, R., Bolch, T., Kawishwar, P., Dobhal, D.P., Srivastava, D. and Pratap, B., 2013. Heterogeneity in glacier response in the upper Shyok valley, northeast Karakoram. The Cryosphere, 7, pp.13851398.

Bamber, J.L. and Rivera, A., 2007. A review of remote sensing methods for glacier mass balance determination. Global Planet Change, 59, pp.138-148.

Bhardwaj, A., Joshi, P.K., Sam, L., Singh, M.K., Singh, S. and Kumar, R., 2015. Applicability of Landsat 8 data for characterizing glacier facies and supraglacial debris. Int J Appl Earth Obs Geoinf., 38, pp.51-64.

Bolch, T., Kulkarni, A., Kääb, A., Huggel, C., Paul, F., Cogley, J. G., Frey, H., Kargel, J. S., Fujita, K., Scheel, M., Bajracharya, S. and Stoffel, M., 2012. The State and Fate of Himalayan Glaciers. Science, 336(6079), pp.310-314.

Dey, B., Goswami, D.C., Rango, A., 1983. Utilization of satellite snow cover observations for seasonal streamflow estimates in the Western Himalaya. Nord Hydrol 14, pp.257-266.

Dimri, A.P., Niyogi, D., Barros, A.P., Ridley, J., Mohanty, U. C., Yasunari, T. and Sikka, D.R., 2015. Western Disturbances: A review, Rev. Geophys., 53, pp.225-246.

Dobhal, D.P., Gergan, J.T. and Thayyen, R.J., 2008. Mass balance studies of the Dokriani Glacier from 1992 to 2000, Garhwal Himalaya, India. Bull Glaciol Res Jpn Soc Snow Ice 25, pp.9-17. 
ESA-SNAP, 2017. Sentinel-1 Toolbox, version 5.0 http://step.esa.int/main/toolboxes/sentinel-1-toolbox/.

Farr, T.G., Rosen, P.A., Caro, E., Crippen, R., Duren, R., Hensley, S., Kobrick, M., Paller, M., Rodriguez, E., Roth, L., Seal, D., Shaffer, S., Shimada, J., Umland, J., Werner, M., Oskin, M., Burbank, D., Alsdorf, D., 2007. The Shuttle Radar Topography 30 Mission, Rev Geophys, 45(2), 583-585.

Frey, H. and Paul, F., 2012. On the suitability of the SRTM DEM and ASTER GDEM for the compilation of topographic parameters in glacier inventories. Int. J. Appl. Earth Obs. Geoinf., 18 , pp.480-490.

Gantayat, P., Kulkarni, A.V. and Srinivasan, J., 2014. Estimation of ice thickness using surface velocities and slope: case study of Gangotri glacier, India. J Glaciol., 60(220), pp.277-282.

Gantayat, P., Kulkarni, A.V. and Srinivasan, J., 2014. Estimation of ice thickness using surface velocities and slope: case study at Gangotri Glacier, India. Journal of Glaciology, 60(220), pp.277282 .

Goldstein, R.M., Zebker H.A. and Werner, C.L., 1988. Satellite radar interferometry: two-dimensional phase unwrapping. Radio Sci., 23(4), pp. 713-720.

Gorelick, N., Hancher, M., Dixon, M., Ilyushchenko, S., Thau, D. and Moore, R., 2017. Google earth engine: planetary-scale geospatial analysis for everyone. Remote Sens. Environ., 202, pp.18-27.

Hallikainen, M., Pulliainen, J., Praks, J., and Arslan, A., 2001. Progress and challenges in radar remote sensing of snow. In: Proceedings of the Third International Symposium on Retrieval of Bio- and Geophysical Parameters from SAR Data for Land Applications, 11-14 September, 2001 in Sheffield, UK. Edited by A. Wilson, scientific coordination by S. Quegan. ESA SP-475, Noordwijk, Netherlands: ESA Publications Division, ISBN 929092-741-0, pp.185 - 192.

Jain, S.K., Goswami, A. and Saraf, A.K., 2009. Role of elevation and aspect in snow distribution in Western Himalaya. Water Resour Manag., 237, pp.1-83.

Jain, S.K., Goswami, A., Saraf, A.K., 2010. Snowmelt runoff modelling in a Himalayan basin with the aid of satellite data. Int J Remote Sens., 31(24), pp.6603-6618.

Joughin, I., Smith, B.E. and Abdalati, W., 2010. Glaciological advances made with interferometric synthetic aperture radar. Journal of Glaciology, 56(200), pp. 1026-1041.

Kulkarni, A., Rathore, B.P., Singh, S.K. and Ajai, A., 2010. Distribution of seasonal snow cover in central and Western Himalaya. Ann Glaciol., 51(54), pp.121-128.

Kumar, V., Venkataramana, G. and Hogda, K.A., 2011. Glacier surface velocity estimation using SAR interferometry technique applying ascending and descending passes in Himalaya. Int $J$ Appl Earth Obs Geoinform., 13, pp.545-551.

Nagler, T. and Rott. H., 2000. Retrieval of wet snow by means of multitemporal SAR data. IEEE Trans Geosci Remote Sens., 38(2), pp.754-765.

Naha, S., Thakur, P.K., Aggarwal, S.P., 2016. Hydrological modelling and data assimilation of satellite snow cover area using a land surface model, VIC. The International Archives of the Photogrammetry, Remote Sensing and Spatial Information Sciences, vol. XLI-B8, 2016, XXIII ISPRS congress, 12-19 July, 2016, Prague, Czech Republic https://doi.org/10.5194/isprsarchives-XLI-B8-353-2016.
Nikam, B.R., Garg, V., Gupta, P.K., Thakur, P.K., Kumar, A.S., Chouksey, A., Aggarwal, S.P., Dhote P. and Purohit, S., 2017. Satellite-based mapping and monitoring of heavy snowfall in North Western Himalaya and its hydrologic consequences, Current science, 113(12), pp. 2328-2334.

Paterson, W.S.B., 1994. Physics of Glaciers. Third Edition. Butterworth-Heinemann, p. 480.

Patrington, K. C., 1998. Discrimination of glacier facies using multi-temporal SAR data, Journal of Glaciology, 44(146), pp. $42-53$.

Pellika, P., and Rees, W.G., 2009. Remote Sensing of Glaciers. Taylor \& Francis, 330 pp.

Pepin, N. C., and Lundquist, J. D., 2008. Temperature trends at high elevations: patterns across the globe. Geophys. Res. Lett. 35, L14701.

Pratap, B., Dobhal, D.P., Bhambri, R., Mehta, M. and Tewari, V.C., 2016. Four decades of glacier mass balance observations in the Indian Himalaya. Reg Environ Change, 16, pp.643-658.

Prasad, V.H. and Roy, P.S., 2005. Estimation of snowmelt runoff in Beas Basin, India. Geocarto Int., 20(2), pp.41-47.

Rees, W.G., 2006. Remote sensing of snow and ice. CRC Press, Boca Raton.

Schaner, N., Voisin, N., Nijssen, B. and Lettenmaier, D.P., 2012. The contribution of glacier melt to streamflow. Environ. Res. Lett., 7, 034029, 8 pages.

Sharma, V., Mishra, V.D. and Joshi P.K., 2014. Topographic controls on spatio-temporal snow cover distribution in northwest Himalaya. Int J Remote Sens., 35(9):3036-3056.

Sharma, A. K., Singh, S.K., Kulkarni, A.V. and Ajai, 2013. Glacier inventory in Indus, Ganga and Brahmaputra Basins of the Himalaya. Natl. Acad. Sci. Lett. 36 (5): 497-505.

Shi, J. and Dozier, J. 2000. Estimation of snow water equivalence using SIR-C/X SAR, Part I: inferring snow density and subsurface properties. IEEE Trans Geosci Remote Sens., 38, pp.2465-2474.

Singh, P. and Jain, S.K., 2002. Snow and glacier melt in the Satluj River at Bhakra Dam in the Western Himalayan region. Hydrol Sci J., 47, pp.93-106.

Singh, P. and Singh, V.P., 2001. Snow and glacier hydrology. Water science and technology, Vol. 37. Kluwer Academic Publishers, Dordrecht.

Singh, P., and Kumar, N., 1997. Impact assessment of climate change on the hydrological response of a snow and glacier melt runoff dominated Himalayan River, J. Hydrol., 193, pp.316-350.

Singh, G. and Venkataraman, G., 2007. Snow wetness estimation using advanced synthetic aperture radar data. J Appl Remote Sens., 1, pp.013521.

Singh, G. and Venkataraman, G., 2009. Snow density estimation using polarimetric ASAR data. In: Proceedings of IEEE IGARSS09, 2, pp II-630-II-633.

Snapir, B., Momblanch, A., Jain., S.K., Waine, T.W. and Holman, I.P., 2019. A method for monthly mapping of wet and dry snow using Sentinel-1 and MODIS: Application to a Himalayan river basin. International Journal of Applied Earth Observation and Geoinformation, 74, pp.222-230. 
Sood S., 2015. Glacier Classification and Movement Estimation using SAR Polarimetric and Interferometric Techniques. IIRSITC joint Master of Science in Geoinformation Science and Earth Observation (MSc) thesis of University of Twente, pp. 1-83.

Space Application Centre, SAC, 2016. Monitoring snow and glaciers of Himalayan region, Space Applications Centre, ISRO, Ahmedabad, India. ISBN: 978-93-82760-24-5.

Thakur, P.K., Aggarwal, S.P., Radchenko, Y., 2009. Snow melt runoff and climate change studies in Manali sub-basin of Beas River, India. In: Proceedings of national symposium on climate change and water resources in India (CCWRIN), IAH, 18-19 Nov, NIH Roorkee, India.

Thakur, P.K., Aggarwal, S.P., Garg, P.K., Garg, R.D., Mani, S., Pandit, A. and Kumar, S., 2012. Snow physical parameter estimation using space based SAR. Geocarto Int., 27, pp.263288

Thakur, P.K., Garg, P.K., Aggarwal, S.P., Garg, R.D. and Mani, S., 2013. Snow cover area mapping using synthetic aperture radar in Manali watershed of Beas River in the Northwest Himalayas. J. Indian Soc. Remote Sens., 41(4), 933-945.

Thakur, P.K., 2014. Snow Melt Runoff Status in Part of Ganga Basin, Chapter 10, R. Sanghi (ed.), Our National River Ganga: Lifeline of Millions, DOI 10.1007/978-3-319-00530-0_10, C Springer International Publishing Switzerland 2014, pp. 241-260.

Thakur, P.K., Dixit, A., Chouksey, A., Aggarwal, S.P., Kumar, A.S., 2016. Ice sheet features identification, glacier velocity estimation and glacier zones classification using high resolution optical and SAR data. In: SPIE Asia-Pacific remote sensing conference during April 4-7, 2016 at New Delhi, India, Proceedings of SPIE, 9877: 987719-1-16.

Thakur, P.K., Aggarwal, S.P., Arun, G., Sood, S., Kumar, A.S., Mani, S. and Dobhal, D.P., 2017a. Estimation of snow cover area, snow physical properties and glacier classification in parts of Western Himalaya using C-band SAR data. J Indian Soc Remote Sens., 45(3), pp.525-539.

Thakur, P.K., Garg, V., Nikam, B.R., Chouksey, A. and Aggarwal, S.P., 2017b. Remote sensing of snow, glaciers and ice in Indian Himalayan region and parts of Arctic and Antarctica: Current status, advances and future prospects. Proc. Natl. Acad. Sci., India, Sect. A Physical Sciences, 87(4), pp.593-616.

Thayyen, R.J. and Dimri, A.P., 2018. Slope Environmental Lapse Rate (SELR) of Temperature in the Monsoon Regime of the Western Himalaya. Front. Environ. Sci., 6, pp.42, 1-20.

Wagnon, P., Linda, A., Arnaud, Y., Kumar, R., Sharma, P., Vincent, C., Pottaka,1 J.G., Berthier, E., Ramanathan, A., Hasnain, S.I. and Chevallier, P., 2007. Four years of mass balance on ChhotaShigri Glacier, Himachal Pradesh, India, a new benchmark glacier in the Western Himalaya. J Glaciol., 53(183), pp.603-611.

Wangensteen, B., Weydahl, D.J. and Hagen, J.O., 2005. Mapping glacier velocities on Svalbard using ERS tandem DInSAR data. Norsk Geografisk Tidsskrift-Norwegian Journal of Geography, 59, pp.276-285.

Wulf, H., Bookhagen, B. and Scherler, D., 2016. Differentiating between rain, snow, and glacier contributions to river discharge in the western Himalaya using remote-sensing data and distributed hydrological modeling. Adv. Water Resources, 88 , pp.152-169. https://public.wmo.int/en/programmes/global-climateobserving-system/essential-climate-variables.

http://step.esa.int/main/toolboxes/snap/

https://sentinel.esa.int/web/sentinel/missions/sentinel-1 